\title{
The effects of shoreline armouring on estuarine fish are contingent upon the broader urbanisation context
}

\author{
Thomas W. Brook ${ }^{1,2}$, Ben L. Gilby ${ }^{1,2, *}$, Andrew D. Olds ${ }^{1,2}$, Rod M. Connolly ${ }^{3}$, \\ Christopher J. Henderson ${ }^{1,2}$, Thomas A. Schlacher ${ }^{1,2}$ \\ ${ }^{1}$ The ANIMAL Research Centre: health + ecology + conservation; University of the Sunshine Coast, Maroochydore, \\ QLD 4558, Australia \\ ${ }^{2}$ School of Science and Engineering, University of the Sunshine Coast, Maroochydore DC, QLD 4558, Australia \\ ${ }^{3}$ Australian Rivers Institute - Coasts and Estuaries, School of Environment and Science, Griffith University, \\ Gold Coast Campus, Southport 4222, Queensland, Australia
}

\begin{abstract}
Natural ecosystems in estuaries are modified by the effects of runoff from disturbed watersheds and are frequently replaced by armoured estuarine shorelines. Whilst the effects of these 2 stressors are widely recognised, they are typically studied in isolation, and it is not clear how these contrasting types of urbanisation interact to shape faunal assemblages. In this study, fish assemblages were surveyed with underwater videos arranged in a $200 \mathrm{~m}$ grid throughout the lower reaches of 3 estuaries in eastern Australia (resulting in $\geq 63$ sites per estuary and 277 sites in total) which differed in their extent of shoreline and watershed urbanisation. Overall, the least urbanised estuary supported more than twice the number of fish species and a significantly greater abundance of fish. The spatial patterns of fish diversity and abundance within estuaries were related to the proximity of urbanised shorelines, with most fish groups aggregating near armoured shorelines. These effects of distance from urbanised shorelines were, however, modified by the degree to which the entire estuary had been modified. We show that the ecological effects of urbanisation can extend across estuaries and suggest that coastal landscapes should therefore be managed as interlinked mosaics of both natural and artificial habitats.
\end{abstract}

KEY WORDS: Habitat $\cdot$ Mangroves $\cdot$ Spatial ecology $\cdot$ Urbanisation $\cdot$ Watershed

\section{INTRODUCTION}

Human modifications of landscapes are increasing in extent and severity globally (Lotze et al. 2006, Clausen \& York 2008). In urban settings, common ecological consequences of anthropogenic changes include lower habitat quality (Cardinale et al. 2012, Aronson et al. 2014), fewer species at lower abundance (Chapin et al. 2000), lessened ecological functions (such as predation; Barbier et al. 2011), and alterations to the movement of organisms and energy across system boundaries (Massol et al. 2011, Qviström 2017). Whilst urbanisation is generally considered to be ecologically detrimental (McKinney 2002), some species are either not strongly impacted or can even prosper in urban areas (Connell \& Glasby 1999, Beninde et al. 2015, Dafforn et al. 2015). Furthermore, because organisms, matter, and energy move among ecosystems, the effects of urbanisation can have wide-reaching consequences that extend across landscapes (Massol et al. 2011, Qviström 2017). 
Urbanisation is largely a coastal phenomenon, and more than half of the global human population now lives at or near the seashore (Neumann et al. 2015). Impacts of coastal urbanisation can be diverse, including heavy fishing pressure near large coastal cities (Jackson et al. 2001), inputs of sediments, nutrients, and pollutants (Kennish 2002, Pan \& Wang 2012, Liu et al. 2018), and the replacement of natural habitats (e.g. mangroves, wetlands) with armoured shorelines (i.e. shorelines modified by the placement of hard engineering structures such as revetments, concrete walls, rip raps, jetties, and piers) (Bulleri \& Chapman 2010, Munsch et al. 2017). Whilst our understanding of the ecological effects of urbanisation is increasing (Elliott et al. 2014), the degree to which these different stressors interact to modify coastal ecosystems and faunal communities, and the scales over which such changes occur, remain poorly understood (Teichert et al. 2016, Heery et al. 2017).

Estuaries are habitat for many fish species that support commercial and recreational fisheries (Sheaves et al. 2013, Nagelkerken et al. 2015). The replacement of estuarine habitats with armoured shorelines can, therefore, have significant social, cultural, economic, and environmental consequences (Kennish 2002, Lotze et al. 2006, Berendse et al. 2015, Munsch et al. 2017). Armoured shorelines create different feeding and refuge conditions for fish (Barbier et al. 2011) and can therefore modify fish assemblages over multiple spatial scales (Luck 2007, McKinney 2008, Bulleri \& Chapman 2010, Layman et al. 2014, Beninde et al. 2015). As a consequence, the abundance of some fish groups or species might be higher adjacent to armoured shorelines (Hindell 2007, Werry et al. 2012, Rodemann \& Brandl 2017). Alternatively, some fish groups might be particularly sensitive to the removal of natural habitats because their food items are also closely associated with natural habitats (Gittman et al. 2016, Munsch et al. 2016, Kornis et al. 2018). For example, zooplanktivores are most abundant in, or near, mangroves and saltmarshes where their prey, fish and crustacean larvae, are most abundant (Giarrizzo et al. 2011, Davis et al. 2014, Saintilan \& Mazumder 2017). Because most fish species use a number of different ecosystems as habitat (Pittman et al. 2004, Boström et al. 2011, Pittman et al. 2014), it is likely that the impacts of shoreline armouring propagate across seascapes that are functionally linked by fish movement (Sheaves 2009, Rodemann \& Brandl 2017).

Some fish school around structurally complex habitats in coastal seascapes, whether they be natural or artificial, for several key reasons. Structurally com- plex habitats provide areas of calmer waters in their lee, where fish aggregate to save energy (Breitburg et al. 1995, Lenihan 1999), and can be positively related to fish biomass (Gratwicke \& Speight 2005). Structurally complex habitats in estuaries also provide alternate opportunities for feeding because they often support a different assemblage of encrusting and sessile invertebrates than soft coastal substrates. Because of their high structural complexity, these areas also provide small fish with protection from larger predators (Orth et al. 1984, Micheli \& Peterson 1999). For these reasons, fish diversity and abundance are often centralised around structurally complex estuarine habitats, with their assemblages declining in diversity, abundance, and size in the adjacent sandy matrix (Bradley et al. 2017).

Direct modifications to instream estuarine habitat extent and quality, caused by the placement of infrastructure and engineered shore stabilisation, are in many cases supplemented by broader changes to water quality and land use on the estuarine floodplain. In particular, urbanised watersheds can create large loads of sediments, nutrients, and toxicants that lower habitat quality for fish (Halpern et al. 2008), causing local extirpation of species most sensitive to water quality changes (Whitfield \& Elliott 2002, Kornis et al. 2017) and poorer health of fish in urban estuaries (Schlacher et al. 2005, 2007).

Whilst the direct effects of habitat replacement by armoured shorelines are documented at local scales (Bulleri \& Chapman 2010), and the broader effects of environmental quality are described at watershed scales (Elliott et al. 2014), it is not clear how these contrasting stressors combine to affect the distribution of estuarine fish assemblages (but see Breitburg \& Riedel 2005, Bilkovic \& Roggero 2008, Kornis et al. 2017). In this study, we examine how the extent of shoreline armouring and area of remaining verge vegetation (in this case, mangroves) in an estuary interact with how tightly fish are associated with the armoured shorelines. We hypothesised that we would identify more fish and a greater number of fish species at sites closer to armoured shorelines in estuaries with more extensive mangrove forests because the less urbanized ecosystem would support a higher abundance of more sensitive species and has an overall higher carrying capacity. Conversely, we expect fewer fish and lower diversity around armoured shorelines in an estuary with more extensively armoured shorelines and fewer mangroves because of the combined negative impacts from poor habitat quality and extent and reduced environmental heterogeneity. 


\section{MATERIALS AND METHODS}

\section{Study estuaries}

We studied fish responses to urbanisation in 3 subtropical estuaries located in southeast Queensland, Australia (Fig. 1). These estuaries were chosen because they have broadly similar catchment geomorphologies and drain from the same mountain range (Withnall \& Cranfield 2013), have similar bathymetry and river flow rates (see Gilby et al. 2017b), and a similar range of habitats available to fish (see Gilby et al. 2018). The key difference between them, however, is with respect to the area of mangroves and the degree of shoreline armouring in the lower estuary (i.e. areas modified by the placement of hard engineering structures such as revetments, concrete walls, rip raps, jetties, and piers), and the extent of
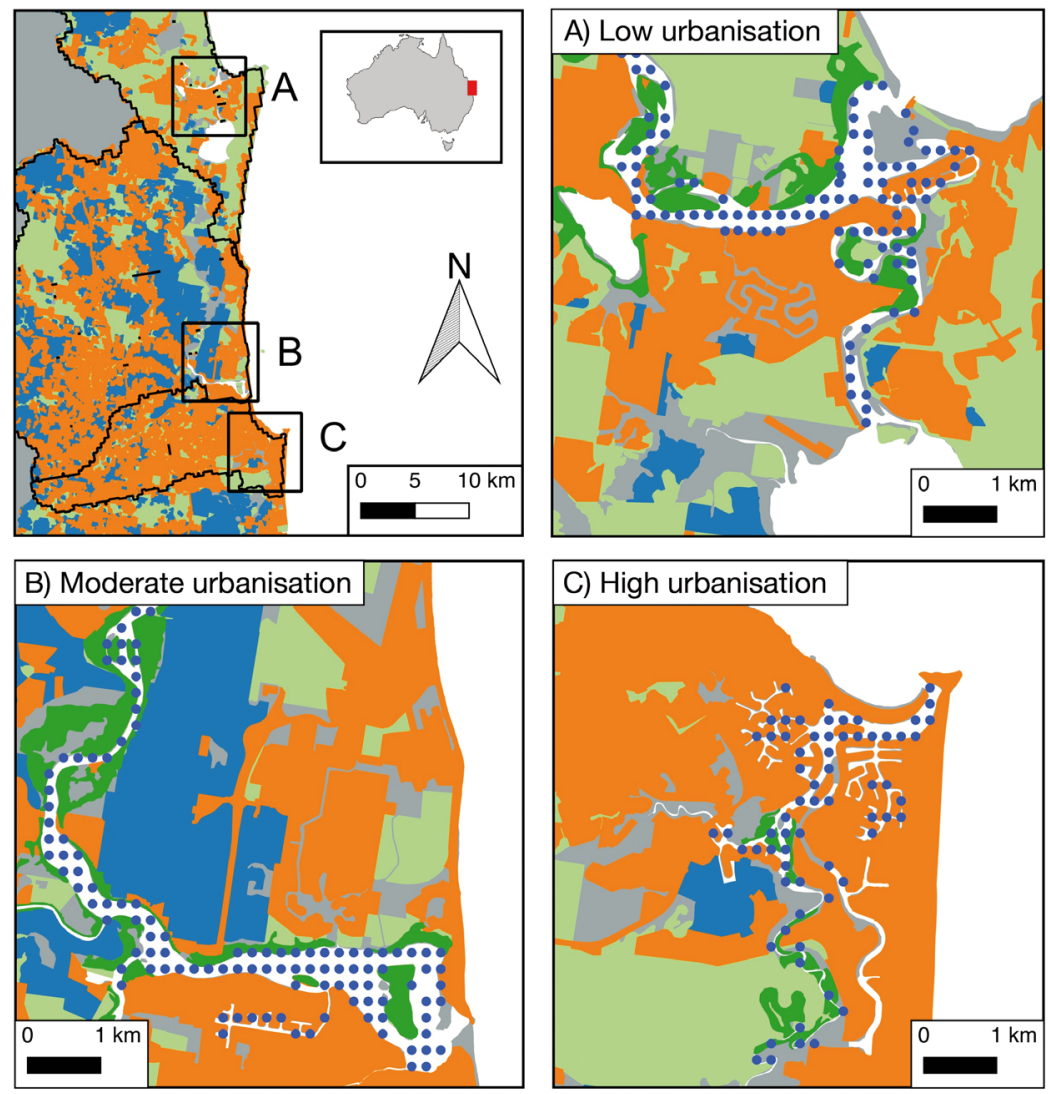

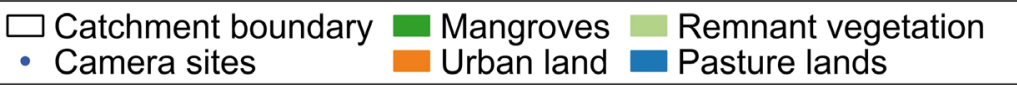

Fig. 1. Location of the 3 study systems in Queensland, Australia, with insets showing the location of fish camera sites within each estuary. (A) Noosa River $(\mathrm{N}=100)$ is characterised by low urbanisation levels and a high cover of remnant mangroves. (B) Maroochy River $(\mathrm{N}=110)$ has moderate urbanisation levels and (C) Mooloolah River $(\mathrm{N}=63)$ has high urbanisation levels, and very low remnant vegetation urbanisation across the watershed (Table 1) (Gilby et al. 2017b). Consequently, we henceforth label the Noosa River as 'low urbanisation', the Maroochy River as 'moderate urbanisation', and the Mooloolah River as 'high urbanisation' for the purpose of this study (Fig. 1, Table 1). For further information on and justification of these categories, see Text S1 and Fig. S1 in the Supplement at www.int-res.com/ articles/suppl/m605p195_supp.pdf.

\section{Fish surveys}

Because salinity is a principal determinant of the distribution of fish in estuaries (Barletta et al. 2005), the extent of surveys in each estuary were standardised to encompass the estuarine reaches from the inlet to the point upstream at which salinity averaged 27 psu over the previous $10 \mathrm{yr}$ (HLWMP 2017). This approach has been used by other studies to standardise the extent of surveys in estuaries across the study area (Gilby et al. 2017b).

Sampling sites were spread evenly across this extent in each estuary in a $200 \mathrm{~m}$ grid, resulting in 100, 110 and 63 sites for the low, moderately and highly urbanised estuaries, respectively (Fig. 1). The grid was not anchored to any specific place in the estuary and was randomly overlaid using GIS. This design was chosen for 2 reasons: (1) a $200 \mathrm{~m}$ spacing between sites lowered the probability of non-independence of observations as individual fish are unlikely to be encountered at more than 1 site during our $30 \mathrm{~min}$ sampling periods (Harvey et al. 2004, Gilby et al. 2016), and (2) it maximised the number of sites and therefore the degree to which we could survey the full extent of seascape heterogeneity in the lower reaches of each estuary (Gilby et al. 2017b).

Fish were sampled with remote underwater video stations (RUVs). RUVs consisted of a camera mounted on a weight (2 kg concrete block), which was raised above the seafloor on a $10 \mathrm{~cm}$ high bracket to expand the field of view. High definition videos were recorded for $30 \mathrm{~min}$ with GoPro Hero 4 cameras $(1960 \times 1080$ pixels at 
Table 1. List of included environmental variables, the ecological hypothesis associated with the variables, the method of data acquisition, the source of data, and mean values for each estuary. 'Estuary-scale measures' refer to factors measured at the scale of the watershed, or the entire sampled stretch of the estuary, whereas 'site-scale measures' are attributes of individual sites measured at small spatial scales $(<500 \mathrm{~m})$

\begin{tabular}{|c|c|c|c|c|c|}
\hline \multirow[t]{2}{*}{ Variable } & \multirow[t]{2}{*}{ Definition } & \multirow{2}{*}{$\begin{array}{l}\text { Data layer } \\
\text { source }\end{array}$} & \multicolumn{3}{|c|}{ U Urbanisation } \\
\hline & & & Low & Moderate & High \\
\hline \multicolumn{6}{|c|}{ Estuary-scale measures } \\
\hline $\begin{array}{l}\text { Extent of armoured } \\
\text { shorelines in the } \\
\text { lower estuary }\end{array}$ & $\begin{array}{l}\text { The percentage of the shoreline of the sampled } \\
\text { stretch of the estuary that is urbanised. Armoured } \\
\text { shorelines are defined as areas modified by the } \\
\text { placement of hard engineering structures such as } \\
\text { revetments, concrete walls, rip raps, jetties, piers, etc }\end{array}$ & $\begin{array}{l}\text { Queensland } \\
\text { Government } \\
\quad(2014)\end{array}$ & $10 \%$ & $10 \%$ & $51 \%$ \\
\hline $\begin{array}{l}\text { Percentage of } \\
\text { watershed } \\
\text { urbanisation }\end{array}$ & $\begin{array}{l}\text { The percentage of the watershed that is urbanised } \\
\text { land. The watershed is defined as all land which } \\
\text { drains through each estuary. Urban areas included } \\
\text { all areas of residential (be they high, or low den- } \\
\text { sity), industrial, transport and communication } \\
\text { (including roads), waste treatment and disposal, } \\
\text { and other service land use. The extent of watershed } \\
\text { urbanization also correlates highly with the extent } \\
\text { of agricultural lands }\left(\mathrm{R}^{2}=0.97\right) \text { and remnant } \\
\text { vegetation }\left(\mathrm{R}^{2}=0.86\right) \text { in the catchment }\end{array}$ & $\begin{array}{l}\text { Queensland } \\
\text { Government } \\
\text { (2014) }\end{array}$ & $8 \%$ & $41 \%$ & $40 \%$ \\
\hline $\begin{array}{l}\text { Area of mangroves } \\
\text { in sampled stretch } \\
\left(\mathrm{m}^{2} \mathrm{~m}^{-1}\right)\end{array}$ & $\begin{array}{l}\text { The area of mangroves in the sampled stretch of the } \\
\text { estuary, divided by the largest 'Distance of site to } \\
\text { estuary mouth' value (see below) for that estuary }\end{array}$ & $\begin{array}{l}\text { Queensland } \\
\text { Government } \\
\text { (2015) }\end{array}$ & 47.7 & 28.9 & 6.2 \\
\hline \multicolumn{6}{|l|}{ Site-scale measures } \\
\hline $\begin{array}{l}\text { Urban land near } \\
\text { site }\left(\mathrm{m}^{2}\right)\end{array}$ & Area of urban land within $500 \mathrm{~m}$ of a site & $\begin{array}{l}\text { Queensland } \\
\text { Government } \\
\quad(2014)\end{array}$ & 206964 & 187599 & 367649 \\
\hline $\begin{array}{l}\text { Mangroves near } \\
\text { site }\left(\mathrm{m}^{2}\right)\end{array}$ & Area of mangroves within $500 \mathrm{~m}$ of a sit & $\begin{array}{l}\text { Queensland } \\
\text { Government } \\
\text { (2015) }\end{array}$ & 106030 & 138803 & 36160 \\
\hline $\begin{array}{l}\text { Distance of site to } \\
\text { estuary mouth (m) }\end{array}$ & $\begin{array}{l}\text { Distance from the site to the centre of the estuary } \\
\text { mouth }\end{array}$ & $\begin{array}{l}\text { Measured in } \\
\text { QGIS (QGIS } \\
\text { Develop- } \\
\text { ment Team } \\
\text { 2017) }\end{array}$ & 3244 & 4593 & 3621 \\
\hline $\begin{array}{l}\text { Distance of site to } \\
\text { armoured estuarine } \\
\text { shoreline }(\mathrm{m})\end{array}$ & $\begin{array}{l}\text { Distance from the site to the nearest armoured } \\
\text { estuarine shoreline }\end{array}$ & $\begin{array}{l}\text { Queensland } \\
\text { Government } \\
\quad(2014)\end{array}$ & 185 & 455 & 386 \\
\hline $\begin{array}{l}\text { Distance of site to } \\
\text { mangroves }(\mathrm{m})\end{array}$ & Distance from the site to the nearest mangroves & $\begin{array}{l}\text { Queensland } \\
\text { Government } \\
\text { (2015) }\end{array}$ & 332 & 213 & 1213 \\
\hline
\end{tabular}

60 frames $\mathrm{s}^{-1}$ ). To maximise water depth and underwater visibility, all RUV deployments were done within $2 \mathrm{~h}$ either side of high tide. Sampling was completed over 4 consecutive days in each estuary, with all 3 estuaries being sampled during 2 wk in May 2017 (late austral autumn) and between the 10:00 and 16:00 h to avoid any crepuscular effects. RUVs were never placed directly in the highly structurally complex ecosystems (i.e. amongst the prop roots of the mangroves). Where they were placed near mangroves or jetty pylons, etc., the video field of view was directed along the edge of the habitat to enable a clear view of fish around the habitat. All sites within each estuary were completed over 3 consecutive days for a total of $9 \mathrm{~d}$ consecutive field time. All estuaries are relatively shallow throughout the sampled stretch (Gilby et al. 2018), so all deployments were made in water depths of less than $6 \mathrm{~m}$.

MaxN, the maximum number of individuals of each fish species visible in video frames at any one 
time, was used to quantify fish assemblages at each site (to at least genus level in all cases). MaxN is the most widely accepted metric for quantifying fish numbers from underwater footage as it provides a conservative estimate of relative fish abundance (Cappo et al. 2003, Dorman et al. 2012).

\section{Quantification of habitat and environmental variables}

We tested for effects of 3 classes of environmental variables that are known to influence the distribution and abundance of fish in estuaries: (1) the area of natural and urban habitats around our sites (in $500 \mathrm{~m}$ buffers) and in the watershed (Gilby et al. 2017a); (2) the distance of sampling sites to mangroves, armoured shorelines, and the estuary mouth (Connolly \& Hindell 2006); and (3) light penetration (secchi disc) and salinity (refractometer) measured on the day of survey at each site (Table 1). We found no significant differences in light or salinity values between our 3 estuaries $(p>0.06)$, and there is little evidence to suggest that these water quality metrics reach levels that either vary too greatly or reach extremes that influence the distribution of fish in the region (Gilby et al. 2016, 2018, Olds et al. 2018), so these were not included as variables in statistical models. The areas of habitats, as well as distances between habitats, were calculated in QGIS (v.2.18.11; QGIS Development Team 2017).

\section{Statistical analyses}

Correlations between the structure of fish assemblages at every RUVS site (i.e. the fish assemblage dataset; a multivariate matrix of the type and number of each species) and the suite of site-scale environmental variables plus the broader categorical factor 'estuary' (i.e. the explanatory variables to which the fish are responding directly) were examined with distance-based linear models (DistLM) in PrimerE (Anderson 2004). Estuary encompasses the multiple differences in estuary-scale environmental measures (especially with respect to the broader levels of urbanisation and remaining mangroves, i.e. low, moderate, and high urbanisation), the interactive nature of these measures, and better reflects environmental measures that fish are responding directly to within coastal ecosystems. We acknowledge that this analysis corresponds to only 1 estuary at each of our 'impact levels' (i.e. $\mathrm{n}=1$ ). The level of intense sampling used in this study precludes any meaningful replication at each impact level. This shortfall is, however, offset by our high level of replication within individual estuaries $(n \geq 63)$. Models were calculated on Modified Gower Log10 dissimilarity measures for the fish assemblage (Anderson et al. 2006) and normalised Euclidean distance for environmental variables. 'Important' environmental variables which are used in subsequent univariate analyses were determined by the outcomes of the sequential tests (i.e. the 'best fit' model) of the DistLM analysis.

Generalised linear models were then used to test for correlations between a suite of descriptive univariate metrics of the fish assemblage and important environmental variables that were identified in DistLM models. All GLMs were fitted with Poisson distributions and conducted in R (R Core Team 2017). We tested 3 types of fish metrics: (1) 'diversity and abundance' (species richness, harvestable fish abundance), which represented descriptors that are often used by environmental managers and in monitoring programs (Whitfield \& Elliott 2002) (Table S1 in the Supplement), (2) 'habitat associations' (mangroveor structure-associated), which represented typical occurrence patterns of fish in regional estuaries as determined by recent studies in estuaries of the region (Olds et al. 2012, Henderson et al. 2017, Gilby et al. 2018) (Table S1), and (3) 'trophic groups' (abundance of piscivores and zooplanktivores) (per Elliott et al. 2007), which represented the typical prey intake and feeding behaviour (Table S1). We selected piscivores because they are more likely to be affected by declines in water clarity (Lunt \& Smee 2015) and are often tightly associated with structured habitats in this region (Gilby et al. 2016, 2018). Conversely, zooplanktivores are often tightly associated with mangroves because mangroves provide their preferred zooplankton prey in great abundance. Zooplanktivores are also particularly sensitive to changes in water quality because these have immediate consequences for planktonic food webs and therefore zooplankton prey (Giarrizzo et al. 2011, Davis et al. 2014, Saintilan \& Mazumder 2017).

\section{RESULTS}

\section{Differences in fish assemblages}

Estuarine fish assemblages were shaped by the combined effects of distance from armoured shorelines and the estuary in which the site was positioned (explaining $4.3 \%$ of total variation; Table 2, Fig. S2 in 
Table 2. Distance-based linear model output showing associations between environmental metrics and variation in fish assem-

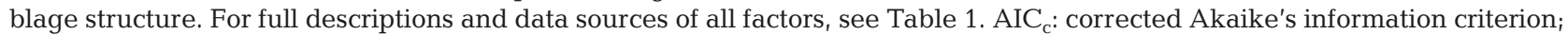
SS: sum of squares

\begin{tabular}{|lccccc|}
\hline Test/variable & $\mathrm{AIC}_{\mathrm{c}}$ & $\mathrm{SS}$ & Pseudo- $F$ & $\mathrm{p}$ & $\begin{array}{c}\text { Variance } \\
\text { explained }\end{array}$ \\
& & & $\begin{array}{c}\text { Cumulative } \\
\text { variance } \\
\text { explained }\end{array}$ \\
\hline Marginal tests & & & & & \\
Estuary & 5.92 & 4.90 & 0.001 & 0.035 \\
Distance of site to armoured estuarine shoreline & 2.66 & 4.35 & 0.008 & 0.016 \\
Distance of site to estuary mouth & 2.03 & 3.30 & 0.028 & 0.012 \\
Distance of site to mangroves & 0.99 & 1.60 & 0.127 & 0.006 \\
Mangroves near site & 0.98 & 1.59 & 0.164 & 0.006 \\
Urban land near site & 0.37 & 0.60 & 0.68 & 0.002 & \\
Sequential tests & & & & & 0.035 \\
+Estuary & -136.84 & 5.9 & 4.9 & 0.001 & 0.035 \\
+Distance of site to armoured estuarine shoreline & -137.31 & 1.5 & 2.5 & 0.046 & 0.009 \\
\hline
\end{tabular}

the Supplement). A total of 62 fish species was recorded. Urbanisation was associated with sizeable variation in species richness between estuaries. The highly and moderately urbanised estuary each supported 19 species, whilst the least urbanised estuary had 53 species. Species accumulation curves support this large difference in fish diversity, with the moderately and highly urbanised estuaries approaching an asymptote, but the least urbanised estuary did not reach an asymptote up to the 100 samples taken (Fig. 2). Species assemblages differed significantly between estuaries (Fig. S2). The most abundant species in the highly-urbanised estuary were yellowfin bream Acanthopagrus australis (an omnivore) and yellowtail scad Trachurus novaezelandiae (a zooplanktivore), each comprising $29 \%$ of total fish abundance (Table S1). In the moderately urbanised estuary, the most abundant species were estuary perchlet

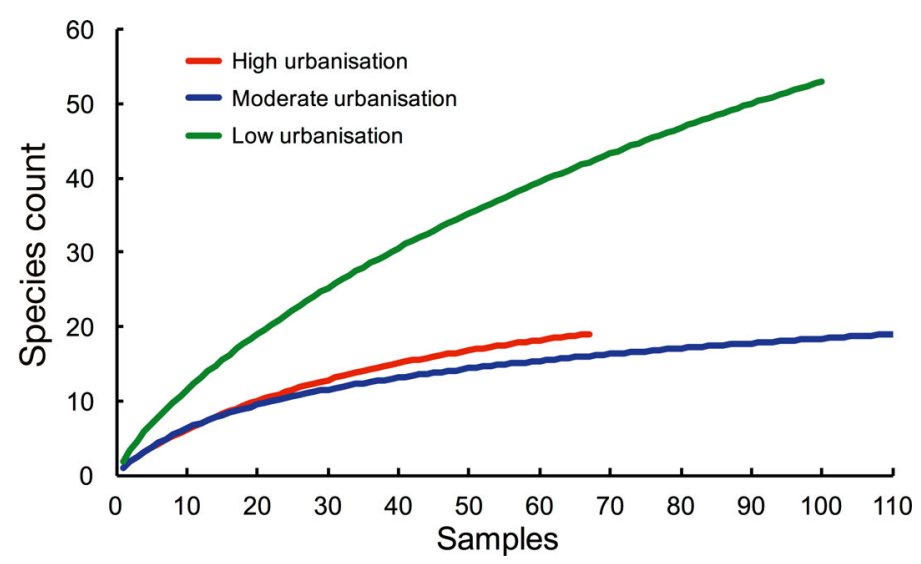

Fig. 2. Species accumulation curves for fish species in 3 estuaries with varying degrees of urbanisation in Queensland, Australia
Ambassis marianus (a zooplanktivore) (30\% of total abundance), yellowfin bream (12\%), and sea mullet Mugil cephalus (a detritivore) (10\%). Similarly, the most abundant species in the least urbanised estuary were also estuary perchlet (28\%), yellowfin bream $(18 \%)$, and sea mullet (12\%) (Table S1).

\section{Effects of urbanisation on fish assemblages}

The extent of catchment and estuarine shoreline armouring strongly modified the spatial response of estuarine fish to armoured shorelines (Fig. 3, Table 3). There were either no clear or very weak distance effects in the most urbanised estuary (Fig. 3). By contrast, we observed distinct clines for several metrics in the 2 estuaries with low or moderate degrees of urbanisation, particularly in terms of species richness and the abundance of harvestable fish species, which generally declined with increasing distance from armoured shorelines (Fig. 3A,B). The strongest distance effects in relation to armoured shorelines were observed for the abundance of piscivores and structure-associated fish: significantly more individuals occurred close to armoured shores and numbers declined sharply farther away (Fig. 3D,E). Similarly, the abundance of mangrove-associated fish declined with increasing distance from armoured shorelines, but only in the moderately and highly urbanised estuaries (Fig. 3C). Zooplanktivores were most abundant in the least urbanised estuary, where their numbers were positively correlated with distance from armoured shorelines (Fig. 3F). By contrast, the abundance of zooplanktivores in moderately and highly urbanised estuaries declined with increasing distance from armoured shorelines (Fig. 3F). 


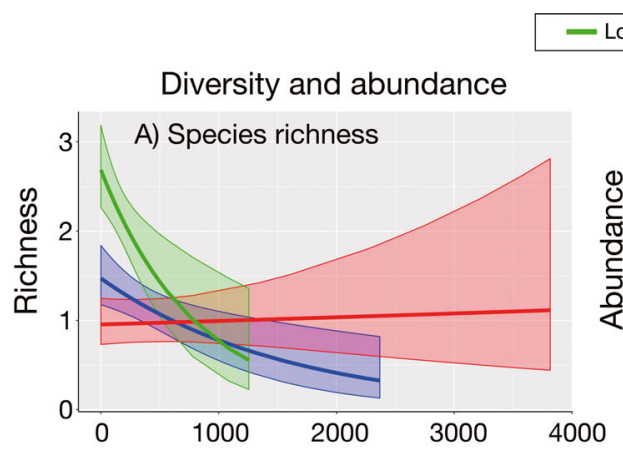

- Low urbanisation - Moderate urbanisation - High urbanisation
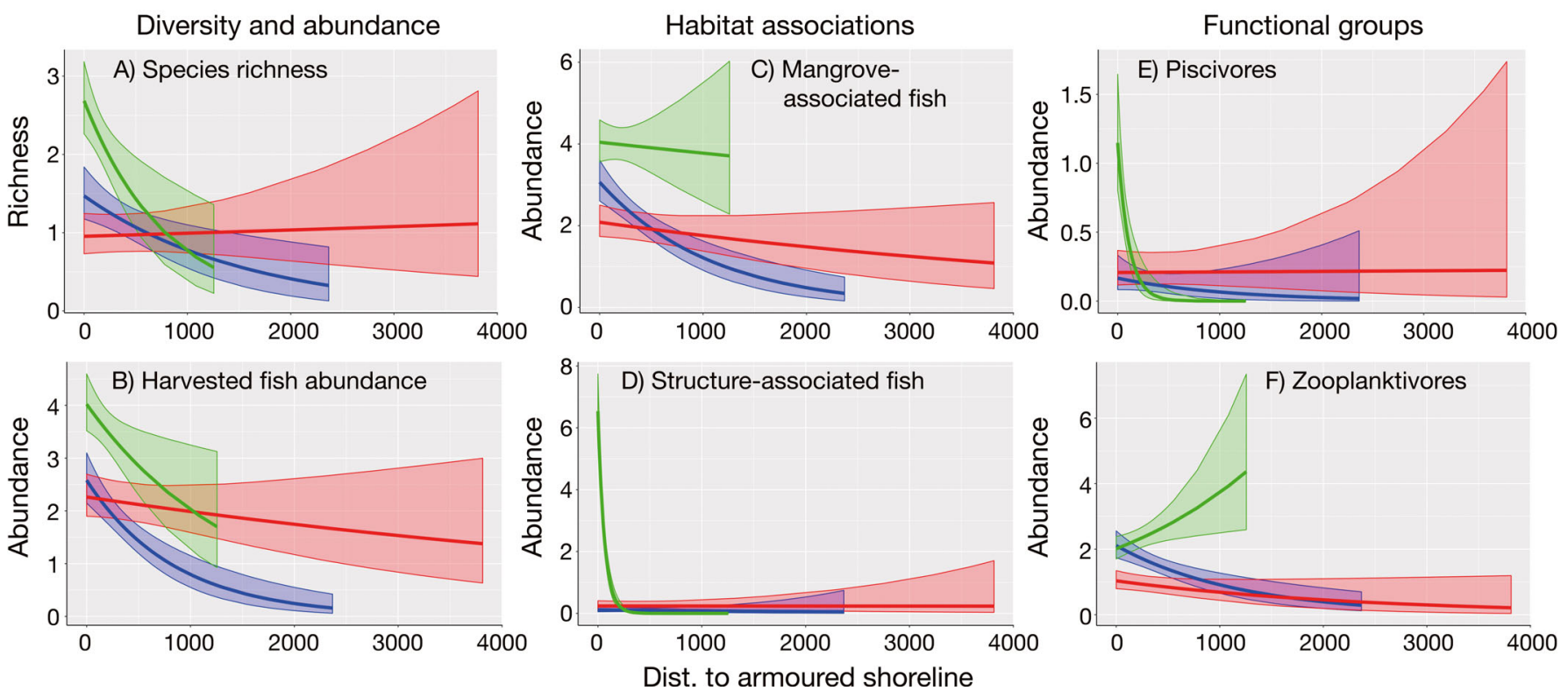

Fig. 3. Generalised linear models illustrating variation in the effects of proximity to armoured shorelines on fish assemblages from estuaries that differ in their extent of urban modification for the abundance of $(A, B)$ indicator groups: $(A)$ species richness and (B) harvested fish abundance; $(\mathrm{C}, \mathrm{D})$ habitat-association groups: (C) mangrove-associated fish and (D) structure-associated fish, and $(E, F)$ functional groups: (E) piscivores and $(F)$ zooplanktivores. Shaded areas are $95 \%$ confidence intervals

Table 3. Summary of generalised linear models testing for relationships between fish metrics (response) and 2 predictors: distance of site to armoured estuarine shoreline (DA) and estuary (Es)

\begin{tabular}{|lrcc|}
\hline Targets/source & df & $\chi^{2}$ & $\mathrm{p}$ \\
\hline Management targets & & & \\
Species richness & & & \\
DA & 1 & 13.86 & $<0.001$ \\
Es & 2 & 54.02 & $<0.001$ \\
DA $\times$ Es & 2 & 6.23 & 0.04 \\
Harvestable fish abundance & & & \\
DA & 1 & 35.31 & $<0.001$ \\
Es & 2 & 70.02 & $<0.001$ \\
DA $\times$ Es & 2 & 13.33 & $<0.002$ \\
Habitat associations & & & \\
Mangroves & & & \\
DA & 1 & 16.89 & $<0.001$ \\
Es & 2 & 79.41 & $<0.001$ \\
DA $\times$ Es & 2 & 17.86 & $<0.001$ \\
Structure & & & \\
DA & 1 & 146.64 & $<0.001$ \\
Es & 2 & 327.55 & $<0.001$ \\
DA $\times$ Es & 2 & 69.22 & $<0.001$ \\
Functional groups & & & \\
Piscivores & & & \\
DA & 1 & 19.29 & $<0.001$ \\
Es & 2 & 27.15 & $<0.001$ \\
DA $\times$ Es & 2 & 18.03 & $<0.001$ \\
Zooplanktivores & & & \\
DA & 1 & 2.22 & 0.14 \\
Es & 2 & 49.21 & $<0.001$ \\
DA $\times$ Es & 2 & 26.38 & $<0.001$ \\
\hline
\end{tabular}

\section{DISCUSSION}

The consequences of removing natural vegetation from watersheds and the impacts of armouring of estuarine shorelines on coastal fishes are widely recognised, but these effects have typically been studied in isolation (Bulleri \& Chapman 2010, Bishop et al. 2017, Heery et al. 2017; but see Breitburg \& Riedel 2005, Bilkovic \& Roggero 2008, Kornis et al. 2017). Consequently, it is not clear whether, and to what extent, these different effects of urbanisation interact to shape fish assemblages (Clynick et al. 2008, Bulleri \& Chapman 2010, Sheaves et al. 2010). In this study, fish diversity and abundance typically decreased with increasing distance from armoured shorelines, irrespective of the broader levels of shoreline armouring in the estuary. In this sense, it is possible that armoured shorelines provide some value for some species of fish in these estuaries. On top of this, we found that the number and type of fish that congregated near urban structure were higher in the least urbanised estuary and scaled to the lowest values in the most urbanised estuary. This finding suggests that whilst armoured shorelines can provide some value for some species of fish, the number of fish that congregate around them is likely contingent on the broader urbaniza- 
tion context of the rest of the estuary (principally mangrove extent, but also total shoreline armouring and watershed urbanization). Alternatively, this finding could suggest that the abundance of urban structure-associated fish might not be modified by landscape-scale urbanization; a hypothesis that would support our finding of strong habitat associations in even the lowest urbanized estuary. Any human modification to estuarine ecosystems will be likely to have negative consequences for some species (e.g. there may have been species already lost from our systems due to this level of urbanization). However, it might be possible to maintain the broader values of the estuaries if natural vegetation is maintained. These findings have significant consequences for the management of natural ecosystems in urban estuaries because they suggest that maintaining natural ecosystems, like mangroves, across coastal seascapes is essential for maximising both fish diversity in estuaries and the habitat values of armoured shorelines for many fishes.

Coastal vegetation loss, especially of mangroves, is one of the most significant impacts on coastal ecosystems (Barbier et al. 2011, Gibbes et al. 2014, Sheaves et al. 2015). In this study, the richness and abundance of most components of the fish assemblage were highest in the least urbanised estuary - the estuary with the largest extent of mangroves. This result concurs with the hypothesis that estuaries with highly urbanised abutting land and catchments contain fewer fish and lower biodiversity overall (Browne \& Chapman 2014). These findings are likely a result of 2 key stressors on estuarine biota. Firstly, poorer water quality in more urbanised estuaries due to greater sediment (Sheaves et al. 2014), pollutant (Waltham \& Connolly 2007), and nutrient runoff (Barbier et al. 2011) from altered catchments filters out sensitive species that are vulnerable to fluctuations in these physico-chemical attributes of estuarine waters (Whitfield \& Elliott 2002). Secondly, replacement of natural habitat throughout estuaries with armoured shorelines (as has occurred in our highly urbanised estuary) reduces habitat heterogeneity (Waltham \& Connolly 2011), removes critical nursery and spawning habitats (Nagelkerken et al. 2015), and limits the abundance of fish groups that are particularly vulnerable to these sorts of impacts (in this instance, zooplanktivores, for example; Sheaves et al. 2015). Combined, the outcome is reduced biodiversity and fish abundance within highly urbanised estuaries (Sheaves et al. 2010, Heery et al. 2017) and a homogenisation of assemblages across seascapes (McKinney \& Lockwood 1999, McKinney 2006).
The movement of organisms, matter, and energy across seascapes means that the effects of urbanisation are rarely confined to the armoured shorelines themselves (Lee et al. 2006). In this study, we found that fish abundance or richness was consistently higher at sites nearer to armoured shorelines. Fish abundance and richness metrics typically declined with increasing distance from armoured shorelines, irrespective of the level of watershed urbanisation. Overall, the ecological effects of urbanisation in highly urbanised estuaries resulted in the lowest fish diversity and abundance, and these impacts did not decline as with increasing distance from armoured shorelines. The key exceptions include structureassociated fish, which decline very rapidly with increasing distance from armoured shorelines in the least urbanised estuary. The structure-associated species recorded in this study are mostly reef-associated species sensitive to poor water quality (such as butterflyfishes and wrasses; see Table S1) and are therefore usually absent from moderately and highly urbanised estuaries (Gilby et al. 2017a). The remaining fish fauna are a group of highly resilient, mostly generalist species which roam across seascapes and are less associated with structured habitats (i.e. biotic homogenisation) (McKinney 2006, Gilby et al. 2016), resulting in no clear spatial patterns in relation to urban shorelines in the moderately and highly urbanised estuaries.

Determining how key monitoring and biodiversity targets respond to urbanisation is important in optimising monitoring and modifying management actions in the future (Beck et al. 2001). In this study, species richness and harvestable fish abundance, factors often targeted for monitoring and management (Whitfield \& Elliott 2002, Gilby et al. 2017a), were higher in the least urbanised estuary and higher closer to armoured shorelines in all estuaries regardless of the level of urbanisation. Whilst strong trends were found for structure-associated fish, the opposite was true for mangrove-associated fish. The abundance of mangrove-associated fish increased with increasing distance from armoured shorelines in the least urbanised estuary, which might reflect the extensive area of remnant mangroves that provide valuable habitat for mangrove-associated fish throughout this estuary (Peters et al. 2015, Whitfield 2017). By contrast, the abundance of mangrove-associated fish declined with increasing distance from armoured shorelines in both the moderately and highly urbanised estuaries, which support only small patches of mangroves. These findings suggest that remnant mangroves might enhance the habitat value 
of armoured shorelines for fish and show how the loss of mangroves from highly urbanised estuaries can substantially alter estuarine fish assemblages (Peters et al. 2015).

The abundance of fish functional groups can act as indicators of environmental change and disturbance in coastal ecosystems (Whitfield \& Elliott 2002, Sheaves et al. 2010). In this study, piscivorous fish were positively associated with urbanisation at all levels, with piscivore abundance also declining sharply with distance from armoured shorelines in the least urbanised estuary. Piscivores might use armoured shorelines as refuges, taking shelter in calmer waters in the lee of structures between foraging excursions to other habitats or feeding areas because they support an abundance of small fishes from other functional groups. Armoured shorelines might, therefore, partially replace the habitat roles that some natural ecosystems provide for fish, provided that sufficient remnant vegetation remains to maintain the ecological condition of the estuary.

Previous studies have demonstrated zooplanktivores to be highly sensitive to urbanisation at multiple levels (Whitfield 1985). Firstly, the abundance of zooplanktivores is reduced in urbanised estuaries because they are closely associated with natural spawning habitats (especially mangroves; Allen et al. 1995). Secondly, their preferred zooplankton prey items in estuaries, principally crab and fish larvae, are always in higher abundance in natural habitats, especially mangroves and saltmarsh (Morgan 1990). Zooplanktivores are also particularly sensitive to any changes in hydrology and water quality, which modify planktonic food webs, and therefore alter their food resources (Kornis et al. 2017). Finally, zooplanktivores are negatively associated with armoured shorelines, but piscivores, the key predators of smaller zooplanktivores, are positively correlated with armoured shorelines, potentially reflecting predator-avoidance strategies (Whitfield \& Blaber 1978). We suggest that piscivores might, therefore, shelter among the complex structures of armoured shorelines and make feeding migrations to other natural habitats that support a higher abundance of zooplanktivores and other prey items; this hypothesis requires further testing.

This study demonstrates that estuaries with low levels of urbanisation can support a high diversity and abundance of estuarine fishes, which aggregate near high relief habitats, encompassing both natural and man-made structures. Paradoxically, the habitat values of armoured shorelines for fishes appear to be greatest in estuaries that also support mangroves, which are more structurally complex. These findings stress the importance of conserving a diverse seascape where a mosaic of habitat types provides complementary and alternative areas for a diversity of fishes. Consequently, maximising the diversity and abundance of fish in estuaries and optimising the habitat values of armoured shorelines for many species necessitates preservation of natural ecosystems, especially mangroves, across estuarine seascapes. Because fish move regularly between natural and artificial habitats in urban estuaries, it will also be necessary to conserve, and restore, critical spatial linkages (e.g. movement corridors, hydraulic connections) between natural ecosystems and urban fish habitats (Soulé et al. 2004, Olds et al. 2016).

Acknowledgements. This work was funded by SeaWorld Research and Rescue Foundation, Noosa Biosphere Reserve Foundation and Noosa Council. We thank Stephanie Keys, Sarah Thackwray, Cassandra Duncan, Jarren Collins, and Ellen Bingham for assistance in the field.

\section{LITERATURE CITED}

Allen DM, Johnson WS, Ogburn-Matthews V (1995) Trophic relationships and seasonal utilization of salt-marsh creeks by zooplanktivorous fishes. Environ Biol Fishes 42:37-50

Anderson M (2004) DISTLM v. 5: a FORTRAN computer program to calculate a distance-based multivariate analysis for a linear model. Department of Statistics, University of Auckland

Anderson MJ, Ellingsen KE, McArdle BH (2006) Multivariate dispersion as a measure of beta diversity. Ecol Lett 9: 683-693

Aronson MFJ, La Sorte FA, Nilon CH, Katti M and others (2014) A global analysis of the impacts of urbanization on bird and plant diversity reveals key anthropogenic drivers. Proc R Soc B 281:20133330

Barbier EB, Hacker SD, Kennedy C, Koch EW, Stier AC, Silliman BR (2011) The value of estuarine and coastal ecosystem services. Ecol Monogr 81:169-193

*Barletta M, Barletta-Bergan A, Saint-Paul U, Hubold G (2005) The role of salinity in structuring the fish assemblages in a tropical estuary. J Fish Biol 66:45-72

Beck MW, Heck KL Jr, Able KW, Childers DL and others (2001) The identification, conservation, and management of estuarine and marine nurseries for fish and invertebrates: a better understanding of the habitats that serve as nurseries for marine species and the factors that create site-specific variability in nursery quality will improve conservation and management of these areas. Bioscience 51:633-641

* Beninde J, Veith M, Hochkirch A (2015) Biodiversity in cities needs space: a meta-analysis of factors determining intra-urban biodiversity variation. Ecol Lett 18:581-592

* Berendse F, van Ruijven J, Jongejans E, Keesstra S (2015) Loss of plant species diversity reduces soil erosion resistance. Ecosystems 18:881-888 
Bilkovic DM, Roggero MM (2008) Effects of coastal development on nearshore estuarine nekton communities. Mar Ecol Prog Ser 358:27-39

Bishop MJ, Mayer-Pinto M, Airoldi L, Firth LB and others (2017) Effects of ocean sprawl on ecological connectivity: impacts and solutions. J Exp Mar Biol Ecol 492:7-30

Boström C, Pittman SJ, Simenstad C, Kneib RT (2011) Seascape ecology of coastal biogenic habitats: advances, gaps, and challenges. Mar Ecol Prog Ser 427:191-218

Bradley M, Baker R, Sheaves M (2017) Hidden components in tropical seascapes: deep-estuary habitats support unique fish assemblages. Estuaries Coasts 40:1195-1206

Breitburg DL, Riedel GF (2005) Multiple stressors in marine systems. In: Norse E, Crowder L (eds) Marine conservation biology: the science of maintaining the sea's biodiversity. Island Press, Washington, DC, p167-182

* Breitburg DL, Palmer MA, Loher T (1995) Larval distributions and the spatial patterns of settlement of an oyster reef fish: responses to flow and structure. Mar Ecol Prog Ser 125:45-60

Browne MA, Chapman MG (2014) Mitigating against the loss of species by adding artificial intertidal pools to existing seawalls. Mar Ecol Prog Ser 497:119-129

Bulleri F, Chapman MG (2010) The introduction of coastal infrastructure as a driver of change in marine environments. J Appl Ecol 47:26-35

Cappo M, Harvey E, Malcolm H, Speare P (2003) Potential of video techniques to monitor diversity, abundance and size of fish in studies of marine protected areas. World Congress on Aquatic Protected Areas Proc, Australian Society of Fish Biology, p 455-464

* Cardinale BJ, Duffy JE, Gonzalez A, Hooper DU and others (2012) Biodiversity loss and its impact on humanity. Nature 486:59

Chapin FS III, Zavaleta ES, Eviner VT, Naylor RL (2000) Consequences of changing biodiversity. Nature 405:234

Clausen R, York R (2008) Global biodiversity decline of marine and freshwater fish: a cross-national analysis of economic, demographic, and ecological influences. Soc Sci Res 37:1310-1320

* Clynick BG, Chapman MG, Underwood AJ (2008) Fish assemblages associated with urban structures and natural reefs in Sydney, Australia. Austral Ecol 33:140-150

Connell SD, Glasby TM (1999) Do urban structures influence local abundance and diversity of subtidal epibiota? A case study from Sydney Harbour, Australia. Mar Environ Res 47:373-387

Connolly RM, Hindell JS (2006) Review of nekton patterns and ecological processes in seagrass landscapes. Estuar Coast Shelf Sci 68:433-444

Dafforn KA, Glasby TM, Airoldi L, Rivero NK, Mayer-Pinto M, Johnston EL (2015) Marine urbanization: an ecological framework for designing multifunctional artificial structures. Front Ecol Environ 13:82-90

Davis B, Mattone C, Sheaves M (2014) Bottom-up control regulates patterns of fish connectivity and assemblage structure in coastal wetlands. Mar Ecol Prog Ser 500: 175-186

Dorman SR, Harvey ES, Newman SJ (2012) Bait effects in sampling coral reef fish assemblages with stereo-BRUVs. PLOS ONE 7:e41538

Elliott M, Whitfield AK, Potter IC, Blaber SJ, Cyrus DP, Nordlie FG, Harrison TD (2007) The guild approach to categorizing estuarine fish assemblages: a global review. Fish Fish 8:241-268
Elliott M, Cutts ND, Trono A (2014) A typology of marine and estuarine hazards and risks as vectors of change: a review for vulnerable coasts and their management. Ocean Coast Manage 93:88-99

Giarrizzo T, Schwamborn R, Saint-Paul U (2011) Utilization of carbon sources in a northern Brazilian mangrove ecosystem. Estuar Coast Shelf Sci 95:447-457

Gibbes B, Grinham A, Neil D, Olds A and others (2014) Moreton Bay and its estuaries: a sub-tropical system under pressure from rapid population growth. In: Wolanski E (ed) Estuaries of Australia in 2050 and beyond. Springer, New York, NY, p 203-222

Gilby BL, Tibbetts IR, Olds AD, Maxwell PS, Stevens T (2016) Seascape context and predators override water quality effects on inshore coral reef fish communities. Coral Reefs 35:979-990

* Gilby BL, Olds AD, Connolly RM, Yabsley NA and others (2017a) Umbrellas can work under water: using threatened species as indicator and management surrogates can improve coastal conservation. Estuar Coast Shelf Sci 199:132-140

Gilby BL, Olds AD, Yabsley NA, Maxwell PS, Connolly RM, Schlacher TA (2017b) Enhancing the performance of marine reserves in estuaries: just add water. Biol Conserv 210:1-7

Gilby BL, Olds AD, Connolly RM, Maxwell PS, Henderson CJ, Schlacher TA (2018) Seagrass meadows shape fish assemblages across estuarine seascapes. Mar Ecol Prog Ser 588:179-189

Gittman RK, Scyphers SB, Smith CS, Neylan IP, Grabowski $\mathrm{JH}$ (2016) Ecological consequences of shoreline hardening: a meta-analysis. Bioscience 66:763-773

Gratwicke B, Speight MR (2005) The relationship between fish species richness, abundance and habitat complexity in a range of shallow tropical marine habitats. J Fish Biol 66:650-667

*Halpern BS, Walbridge S, Selkoe KA, Kappel CV and others (2008) A global map of human impact on marine ecosystems. Science 319:948-952

* Harvey E, Fletcher D, Shortis MR, Kendrick GA (2004) A comparison of underwater visual distance estimates made by scuba divers and a stereo-video system: implications for underwater visual census of reef fish abundance. Mar Freshw Res 55:573-580

*Heery EC, Bishop MJ, Critchley LP, Bugnot $\mathrm{AB}$ and others (2017) Identifying the consequences of ocean sprawl for sedimentary habitats. J Exp Mar Biol Ecol 492:31-48

* Henderson CJ, Olds AD, Lee SY, Gilby BL, Maxwell PS, Connolly RM, Stevens T (2017) Marine reserves and seascape context shape fish assemblages in seagrass ecosystems. Mar Ecol Prog Ser 566:135-144

* Hindell JS (2007) Determining patterns of use by black bream Acanthopagrus butcheri (Munro, 1949) of reestablished habitat in a south-eastern Australian estuary. J Fish Biol 71:1331-1346

HLWMP (2017) Healthy land and water monitoring program. www.hlw.org.au (accessed 7 April 2017)

Jackson JB, Kirby MX, Berger WH, Bjorndal KA and others (2001) Historical overfishing and the recent collapse of coastal ecosystems. Science 293:629-637

Kennish MJ (2002) Environmental threats and environmental future of estuaries. Environ Conserv 29:78-107

Kornis MS, Breitburg D, Balouskus R, Bilkovic DM and others (2017) Linking the abundance of estuarine fish and 
crustaceans in nearshore waters to shoreline hardening and land cover. Estuaries Coasts 40:1464-1486

Kornis MS, Bilkovic DM, Davias LA, Giordano S, Breitburg DL (2018) Shoreline hardening affects nekton biomass, size structure, and taxonomic diversity in nearshore waters, with responses mediated by functional species groups. Estuaries Coasts 41(Suppl 1):159-179

* Layman CA, Jud ZR, Archer SK, Riera D (2014) Provision of ecosystem services by human-made structures in a highly impacted estuary. Environ Res Lett 9:044009

Lee SY, Dunn RJK, Young RA, Connolly RM and others (2006) Impact of urbanization on coastal wetland structure and function. Austral Ecol 31:149-163

Lenihan HS (1999) Physical-biological coupling on oyster reefs: how habitat structure influences individual performance. Ecol Monogr 69:251-275

K Liu Y, Liu GJ, Yuan ZJ, Liu HQ, Lam PKS (2018) Heavy metals (As, $\mathrm{Hg}$ and $\mathrm{V}$ ) and stable isotope ratios $\left(\delta^{13} \mathrm{C}\right.$ and $\delta^{15} \mathrm{~N}$ ) in fish from Yellow River estuary, China. Sci Total Environ 613-614:462-471

Lotze HK, Lenihan HS, Bourque BJ, Bradbury RH and others (2006) Depletion, degradation, and recovery potential of estuaries and coastal seas. Science 312:1806-1809

Luck GW (2007) A review of the relationships between human population density and biodiversity. Biol Rev Camb Philos Soc 82:607-645

* Lunt J, Smee DL (2015) Turbidity interferes with foraging success of visual but not chemosensory predators. PeerJ 3:e1212

Massol F, Gravel D, Mouquet N, Cadotte MW, Fukami T, Leibold MA (2011) Linking community and ecosystem dynamics through spatial ecology. Ecol Lett 14: 313-323

McKinney ML (2002) Urbanization, biodiversity, and conservation: the impacts of urbanization on native species are poorly studied, but educating a highly urbanized human population about these impacts can greatly improve species conservation in all ecosystems. Bioscience 52: 883-890

McKinney ML (2006) Urbanization as a major cause of biotic homogenization. Biol Conserv 127:247-260

McKinney ML (2008) Effects of urbanization on species richness: a review of plants and animals. Urban Ecosyst 11: 161-176

*McKinney ML, Lockwood JL (1999) Biotic homogenization: a few winners replacing many losers in the next mass extinction. Trends Ecol Evol 14:450-453

Micheli F, Peterson CH (1999) Estuarine vegetated habitats as corridors for predator movements. Conserv Biol 13: 869-881

Morgan SG (1990) Impact of planktivorous fishes on dispersal, hatching, and morphology of estuarine crab larvae. Ecology 71:1639-1652

Munsch SH, Cordell JR, Toft JD (2016) Fine-scale habitat use and behaviour of a nearshore fish community: nursery functions, predation avoidance, and spatiotemporal habitat partitioning. Mar Ecol Prog Ser 557:1-15

Munsch SH, Cordell JR, Toft JD (2017) Effects of shoreline armouring and overwater structures on coastal and estuarine fish: opportunities for habitat improvement. J Appl Ecol 54:1373-1384

Nagelkerken I, Sheaves M, Baker R, Connolly RM (2015) The seascape nursery: a novel spatial approach to identify and manage nurseries for coastal marine fauna. Fish Fish 16:362-371
Neumann B, Vafeidis AT, Zimmermann J, Nicholls RJ (2015) Future coastal population growth and exposure to sealevel rise and coastal flooding - a global assessment. PLOS ONE 10:e0118571

Olds AD, Connolly RM, Pitt KA, Maxwell PS (2012) Primacy of seascape connectivity effects in structuring coral reef fish assemblages. Mar Ecol Prog Ser 462:191-203

Olds AD, Connolly RM, Pitt KA, Pittman SJ and others (2016) Quantifying the conservation value of seascape connectivity: a global synthesis. Glob Ecol Biogeogr 25:3-15

Olds AD, Frohloff BA, Gilby BL, Connolly RM, Yabsley NA, Maxwell PS, Schlacher TA (2018) Urbanisation supplements ecosystem functioning in disturbed estuaries. Ecography, doi:10.1111/ecog.03551

Orth RJ, Heck KL, van Montfrans J (1984) Faunal communities in seagrass beds: A review of the influence of plant structure and prey characteristics on predator-prey relationships. Estuaries 7:339-350

Pan K, Wang WX (2012) Trace metal contamination in estuarine and coastal environments in China. Sci Total Environ 421-422:3-16

* Peters JR, Yeager LA, Layman CA (2015) Comparison of fish assemblages in restored and natural mangrove habitats along an urban shoreline. Bull Mar Sci 91:125-139

* Pittman S, McAlpine C, Pittman K (2004) Linking fish and prawns to their environment: a hierarchical landscape approach. Mar Ecol Prog Ser 283:233-254

Pittman SJ, Monaco ME, Friedlander AM, Legare B and others (2014) Fish with chips: tracking reef fish movements to evaluate size and connectivity of Caribbean marine protected areas. PLOS ONE 9:e96028

QGIS Development Team (2017) QGIS Geographic Information System. http://qgis.osgeo.org/

Queensland Government (2014) Queensland land-use mapping program. Southeast Queensland natural resource management region. Queensland Government, Brisbane

Queensland Government (2015) Regional ecosystem mapping. Queensland Government, Brisbane

Qviström M (2017) Landscape histories of urbanisation. Landsc Res 42:239-242

R Core Team (2017) R: a language and environment for statistical computing. R Foundation for Statistical Computing, Vienna. www.r-project.org

Kodemann JR, Brandl SJ (2017) Consumption pressure in coastal marine environments decreases with latitude and in artificial vs. natural habitats. Mar Ecol Prog Ser 574: 167-179

Saintilan N, Mazumder D (2017) Mass spawning of crabs: ecological implications in subtropical Australia. Hydrobiologia 803:239-250

Schlacher TA, Liddell B, Gaston TF, Schlacher-Hoenlinger M (2005) Fish track wastewater pollution to estuaries. Oecologia 144:570-584

Schlacher TA, Mondon JA, Connolly RM (2007) Estuarine fish health assessment: evidence of wastewater impacts based on nitrogen isotopes and histopathology. Mar Pollut Bull 54:1762-1776

Sheaves M (2009) Consequences of ecological connectivity: the coastal ecosystem mosaic. Mar Ecol Prog Ser 391: $107-115$

Sheaves M, Johnston R, Connolly RM (2010) Temporal dynamics of fish assemblages of natural and artificial tropical estuaries. Mar Ecol Prog Ser 410:143-157

Sheaves M, Johnston R, Johnson A, Baker R, Connolly RM (2013) Nursery function drives temporal patterns in fish 
assemblage structure in four tropical estuaries. Estuaries Coasts 36:893-905

Sheaves M, Brookes J, Coles R, Freckelton M, Groves P, Johnston R, Winberg P (2014) Repair and revitalisation of Australia $\mathrm{s}$ tropical estuaries and coastal wetlands: opportunities and constraints for the reinstatement of lost function and productivity. Mar Policy 47:23-38

Sheaves M, Baker R, Nagelkerken I, Connolly RM (2015) True value of estuarine and coastal nurseries for fish: incorporating complexity and dynamics. Estuaries Coasts 38:401-414

Soulé ME, Mackey BG, Recher HF, Williams JE and others (2004) The role of connectivity in Australian conservation. Pac Conserv Biol 10:266-279

Teichert N, Borja A, Chust G, Uriarte A, Lepage M (2016) Restoring fish ecological quality in estuaries: implication of interactive and cumulative effects among anthropogenic stressors. Sci Total Environ 542:383-393

Waltham NJ, Connolly RM (2007) Artificial waterway design affects fish assemblages in urban estuaries. J Fish Biol 71:1613-1629

Waltham NJ, Connolly RM (2011) Global extent and distri-

Editorial responsibility: Jana Davis,

Annapolis, Maryland, USA bution of artificial, residential waterways in estuaries. Estuar Coast Shelf Sci 94:192-197

Werry JM, Lee SY, Lemckert CJ, Otway NM (2012) Natural or artificial? Habitat-use by the bull shark, Carcharhinus leucas. PLOS ONE 7:e49796

Whitfield AK (1985) The role of zooplankton in the feeding ecology of fish fry from some southern African estuaries. Afr Zool 20:166-171

Whitfield AK (2017) The role of seagrass meadows, mangrove forests, salt marshes and reed beds as nursery areas and food sources for fishes in estuaries. Rev Fish Biol Fish 27:75-110

Whitfield AK, Blaber SJM (1978) Food and feeding ecology of piscivorous fishes at Lake St Lucia, Zululand. J Fish Biol 13:675-691

Whitfield AK, Elliott A (2002) Fishes as indicators of environmental and ecological changes within estuaries: a review of progress and some suggestions for the future. J Fish Biol 61:229-250

Withnall IW, Cranfield LC (2013) Queensland minerals geological framework. Department of Natural Resources, Mines and Energy, Queensland, Brisbane

Submitted: January 19, 2018; Accepted: September 12, 2018 Proofs received from author(s): October 4, 2018 